\title{
Vegetative and productive responses of tabasco pepper to fertigation and plastic mulching
}

\author{
Sérgio Weine Paulino Chaves $^{1 \oplus}$, Rubens Duarte Coelho ${ }^{2}$, Jéfferson de Oliveira Costa ${ }^{2 *} \odot$, Sergio André Tapparo ${ }^{3 \oplus}$
}

'Universidade Federal Rural do Semiárido - Depto. de Ciências Agronômicas e Florestais, R. Francisco Mota, 572 59625-900 - Mossoró, RN - Brasil.

²Universidade de São Paulo/ESALQ - Depto. de Engenharia de Biossistemas, C.P. 09 - 13418-900 - Piracicaba, SP Brasil.

${ }^{3}$ Instituto Federal do Mato Grosso do Sul - Campus Ponta Porã, Rod. BR-463, km 14 - 79909-000 - Ponta Porã, MS - Brasil.

*Corresponding author <costajo@alumni.usp.br>

Edited by: Mohammad Valipour

Received March 25, 2021

Accepted June 20, 2021
ABSTRACT: The use of plastic mulching and high frequency hydroponic drip irrigation (intensive production methods) watering cycle may increase tabasco pepper crop production per unit area. To test this hypothesis, two randomized block experiments were conducted in a greenhouse, using a $2 \times 4$ factorial scheme with two contrasting soil types (sandy loam and loamy soil), two mulching conditions of soil cover (SC), and no soil cover (NC) at four frequencies: 1, 3, 12, and 24 irrigations every three days. The growth and yield pepper components were evaluated and the water use efficiency (WUE) was calculated. Mulching did increase fruit dry mass percentage (FDMP), WUE, and potassium use efficiency (KUE) in sandy loam soil. The greater frequency fertigation did not increase fruit fresh mass (FFM), number of fruits (NF), fruit average mass (FAM), fruit dry mass (FDM), FDMP, or WUE in sandy loam and loamy soils. Tabasco pepper has a permanent shrub growth habit that is somewhat different from horticultural crops, besides it is usually responsive to high frequency irrigation under vegetative intensive growth.

Keywords: Capsicum frutescens L., greenhouse, soil cover, water use efficiency

\section{Introduction}

Intensive production methods, including the use of plastic mulching and drip irrigation operated at a high frequency watering cycle may favor pepper crop production (Gerçek and Demirkaya, 2021; Kabir et al., 2021). The vegetative and productive responses of plants in general are related to better phytotechnical management of edaphoclimatic conditions (Alenazi et al., 2015; Ćosić et al., 2017).

The effects of fertigation and plastic mulching on vegetative and productive responses of crops have been recently investigated by many scientists. According to Vázquez et al. (2006), mulching can save up to $20 \%$ of the water required for tomato cultivation. Zong et al. (2021) indicated that mulching of a cotton crop significantly increased soil water content compared to bare soil growth and was associated to greater plant height, leaf area index (LAI), photosynthetic rate, and aboveground biomass accumulation. Zhang et al. (2019) found that plastic mulching improved maize grain yield, radiation efficiency, water, and nitrogen use. Ding et al. (2019) studied the effects of continuous plastic mulching on crop growth in a winter wheat-summer maize rotation system in the Loess Plateau of China and suggested that plastic mulching effectively accelerated wheat leaf appearance and tiller node development, increasing the final spike number and grain yield. For maize, mulching increased the number of kernels per spike and the thousand-seed weight, significantly improving crop yield. Liao et al. (2021) used three mulching methods and three irrigation strategies to demonstrate the effects on soil environment, growth, and yield of apple trees and indicated that mulching and irrigation significantly increased the net photosynthetic rate of leaves and crop yield.
Previous studies were mainly concerned with annual and perennial crops grown at an open field scale and no previous study assessed pepper response to mulching treatments and drip irrigation frequencies (Wang et al., 2021a; Zhou et al., 2021). The investigation of irrigation water use efficiency (WUE) and nutrient use efficiency (NUE) applied via fertigation in pepper crops cultivated under greenhouse conditions is innovative. The use of plastic mulching is considered a primary solution to improve crop productivity worldwide (Wang et al., 2021b; Zhang et al., 2021). However, the technical aspects of this management practice on the growth of pepper crop and its productivity are not clearly understood.

Thus, this study evaluated the effects of plastic mulching and frequency of hydroponic fertigation on the vegetative and productive aspects of the pepper, Capsicum frutescens L., cv. Tabasco Mcllhenny, on two soil types Oxisol (Typic Ustox) of sandy loam texture and Ultisol (Typic Udults) of loamy texture.

\section{Materials and Methods}

\section{Study site}

The study was conducted in a greenhouse in the municipality of Piracicaba, São Paulo State, Brazil, (22 $46^{\prime} 39^{\prime \prime} \mathrm{S}, 47^{\circ} 17^{\prime} 45^{\prime \prime} \mathrm{W}$, altitude $570 \mathrm{~m}$ ) (Costa et al., 2020; Tapparo et al., 2019). The greenhouse consisted of three spans with arched and semi-detached roofs. However, we used two spans with dimensions of $14 \mathrm{~m}$ wide and $22 \mathrm{~m}$ long, with a galvanized metallic structure, height in the central part of $4 \mathrm{~m}$ and a ceiling height of $2.5 \mathrm{~m}$, consisting of four front windows at the back for ventilation. The sides had a $20 \mathrm{~cm}$ baseboard of reinforced 
concrete and were closed with a protective screen with $50 \%$ shade. Two drainage lysimeters were installed inside the greenhouse, which were $0.8 \mathrm{~m}$ in diameter, $0.5 \mathrm{~m}^{2}$ in area, and $0.6 \mathrm{~m}$ in height. The nutrient solution tanks for fertigation were placed outside the greenhouse.

The climate of the region, according to the Köppen classification, is of the Cwa type (Alvarez et al., 2013), that is, dry winters and warm monthly temperatures greater than $22^{\circ} \mathrm{C}$. The average temperature is $21.6^{\circ} \mathrm{C}$, the average relative humidity is $73 \%$, and the annual precipitation is $1280 \mathrm{~mm}$. The soils of this site were classified as Oxisol (Typic Ustox) with sandy loam texture and Ultisol (Typic Udults) with loamy texture and their main chemical and physical characteristics are given in Table 1.

\section{Treatments and experimental design}

In the greenhouse, two randomized block experiments with four replicates were conducted. The treatments consisted of two soil treatments, soil cover with plastic (SC) and no soil cover (NC), and four irrigation frequencies $(1,3,12$, and 24 times within three days), labeled as: T1, CP and 24; T2, CP and 12; T3, CP and 3 ; T4, CP and 1; T5, SP and 24; T6, SP and 12; T7, SP and 3 ; and T8, SP and 1 (Figure 1). Within each block, the mulching treatments were represented by two plots and the treatments without plastic covering by a single plot. The duplication in SC treatment aimed to ensure greater uniformity in data collection, as this treatment resulted in water and nutrient restriction compared to the NC treatment. Each experiment comprised 48 experimental plots and eight border plants, totaling 56 pots.

\section{Features and application of plastic mulch}

The diffusor plastic film used in these experiments was made in Israel and is widely used for crops in that country because it provides several advantages for production. The film was purchased through a Polysack distributor and has the following specifications: double-sided plastic mulching (silver on top and black on bottom), 25 micron thick fracture resistance stress of $28 \mathrm{MPa}$, elongation of $400 \%$ to fracture, photosynthetically active radiation transmission $<1 \%$ and photosynthetically active radiation reflection $>25 \%$.
Prior to mulching, small amounts of soil were removed from the sides of the pots to place on top of the plastic to hold it in place. Mulching was done by placing the plastic on the soil to allow good contact between the

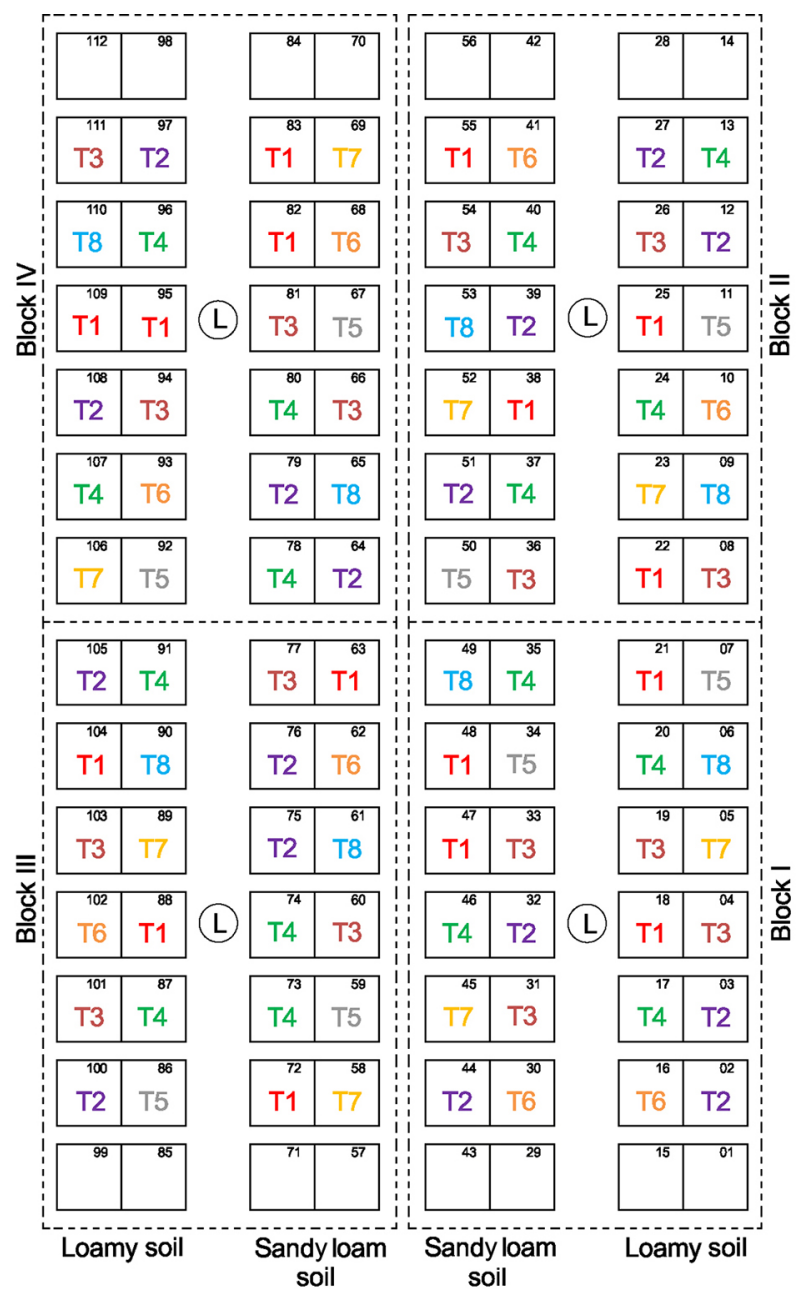

Figure 1 - Sketch of the experimental site: soil cover with plastic (SC) and no soil cover (NC); fertigation frequencies (1, 3, 12 and 24) every three days, denominated: T1 - SC and 24; T2 - SC and 12; T3 - SC and 3; T4 - SC and 1; T5 - NC and 24; T6 - NC and 12; T7 - NC and 3; T8 - NC and 1; Lysimeters (L); The border plants were not considered for the mean values of the evaluated characteristics.

Table 1 - Main chemical and physical characteristics of Oxisol (Typic Ustox) and Ultisol (Typic Udults), used in the experiment.

\begin{tabular}{|c|c|c|c|c|c|c|c|c|c|c|c|}
\hline \multirow{2}{*}{$\begin{array}{l}\mathrm{pH} \\
\mathrm{H}_{2} \mathrm{O} \\
\end{array}$} & \multirow{2}{*}{ P (Mehlich) } & \multirow{2}{*}{$\mathrm{K}$} & \multirow{2}{*}{ MO } & \multirow{2}{*}{$\mathrm{Ca}+\mathrm{Mg}$} & \multirow{2}{*}{$\mathrm{Al}$} & \multirow{2}{*}{$D_{s}$} & \multirow{2}{*}{$D_{p}$} & \multirow{2}{*}{ PT } & \multicolumn{3}{|c|}{ Particle size fractions } \\
\hline & & & & & & & & & Sand & Silt & Clay \\
\hline & \multicolumn{2}{|c|}{$\mathrm{mg} \mathrm{dm}^{-3}$} & $\mathrm{~g} \mathrm{~kg}^{-1}$ & $-\mathrm{cmc}$ & -3 & $\longrightarrow$ & - & $\%$ & 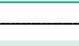 & $\mathrm{g} \mathrm{kg}^{-1}$ & \\
\hline & \multicolumn{11}{|c|}{ Oxisol (Typic Ustox) } \\
\hline \multirow[t]{2}{*}{5.0} & 17.0 & 19.5 & 14.0 & 2.3 & 0.0 & 1.53 & 2.65 & 42.3 & 751 & 78 & 171 \\
\hline & \multicolumn{11}{|c|}{ Ultisol (Typic Udults) } \\
\hline 5.6 & 7.0 & 124.8 & 13.0 & 6.0 & 0.0 & 1.28 & 2.70 & 52.6 & 313 & 148 & 539 \\
\hline
\end{tabular}

Hydrogen potential $(\mathrm{pH})$, phosphorus $(\mathrm{P})$, potassium $(\mathrm{K})$, organic matter $(\mathrm{OM})$, calcium $(\mathrm{Ca})$, magnesium $(\mathrm{Mg})$, aluminum $(\mathrm{All})$, soil density $\left(\mathrm{D}_{\mathrm{s}}\right)$, soil particle density $\left(\mathrm{D}_{\mathrm{p}}\right)$, total soil porosity (PT). 
materials. Then, a small hole was made in the center of the mulch for seedling transplantation.

\section{Seedling production, planting, and crop growth}

The genetic material used was the pepper (Capsicum frutescens L.) cv. Tabasco. The seeds were provided by the McIlhenny Company through the Avaí farming, a company located in Ceará State, Brazil. Seeds were sown in 128 cell trays and, at 57 days after sowing (DAS), the seedlings were transplanted into pots in the greenhouse. The spatial arrangement used for greenhouse planting was in double rows, with a spacing of $2.58 \times 0.92 \mathrm{~m}$ between rows and $1.57 \mathrm{~m}$ between plants, with one seedling per pot, resulting in a population density of 3636 plants $\mathrm{ha}^{-1}$. The plants received two pruning events, resulting in sixteen branches. The first pruning was carried out at seven days after transplanting (DAT), leaving the plant with two pairs of leaves, and the second at $62 \mathrm{DAT}$, leaving the plant with four branches and two pairs of leaves per branch.

Fertilization was performed based on the soil chemical analysis and the following compounds were applied: monoammonium phosphate, simple superphosphate, potassium chloride, zinc sulfate, and boric acid. For sandy loam, the doses per plant were 4 $\mathrm{g} \mathrm{N}, 60 \mathrm{~g} \mathrm{P}_{2} \mathrm{O}_{5}, 18 \mathrm{~g} \mathrm{~K}_{2} \mathrm{O}, 150 \mathrm{mg} \mathrm{SO}$ and $100 \mathrm{mg} \mathrm{B}$. For loamy soil, the doses per plant were $4 \mathrm{~g} \mathrm{~N}, 60 \mathrm{~g} \mathrm{P}_{2} \mathrm{O}_{5}, 12$ $\mathrm{g} \mathrm{K}_{2} \mathrm{O}, 150 \mathrm{mg} \mathrm{SO}, 300 \mathrm{mg} \mathrm{Zn}$ and $100 \mathrm{mg} \mathrm{B}$.

The irrigation system consisted of one dripper per plant. Each dripper was connected to a fourmicrotube discharge divider with dripper piles, evenly positioned in each pot. Irrigation depths were chosen according to total irrigation need (TIN) and soil cover. The TIN was calculated daily from estimates of the crop evapotranspiration $\left(\mathrm{ET}_{\mathrm{c}}\right)$ using drainage lysimeters installed inside the greenhouse. $\mathrm{ET}_{\mathrm{c}}$ was obtained at each crop growth stage, corresponding to the difference between the water volume placed in the lysimeter and the drained volume in liters, divided by the area in $\mathrm{m}^{2}$ equivalent to the crop spacing. The $\mathrm{ET}_{\mathrm{c}}$ estimation started 20 DAT when it was verified that the water storage in the lysimeters was in balance. In addition, 32 tensiometers were installed in 16 plots, at depths 15 and $30 \mathrm{~cm}$ and at a radial distance from the plant of $15 \mathrm{~cm}$ for soil water monitoring.

Flow uniformity tests were carried out on the drippers in the experimental site and the system provided an excellent uniformity of water distribution to the plants (91 \%). This high uniformity value ensured that all parts of the experimental site received about the same amount of water and fertilizer (depending on the treatment), without undesirable variations. The total gross irrigation depths applied at the end of the cultivation cycle were $312 \mathrm{~mm}$ (with mulch) and $459 \mathrm{~mm}$ (without mulch). The $30 \%$ reduction in the irrigation depth was based on the assumption that soil cover could reduce water consumption of pepper plants by $15 \%$ and the high frequency of irrigation could contribute to the other $15 \%$. Amayreh and Al-Abed (2005), during the two consecutive years of 2001 and 2002, found that the water demand of a tomato crop was $36 \%$ lower on average under soil cover mulching in relation to cultivation without cover. Allen et al. (2007) stated that plastic mulching reduced $\mathrm{ET}_{\mathrm{c}}$ by 5 to $30 \%$ compared to bare soil cultivation and crop yields generally increased with the use of plastic mulching. Irrigation frequency was established from the beginning of fruiting (142 DAT), according to the treatments.

Fertigation was performed with the same frequency of irrigation based on nutrient concentrations recommended for hydroponic pepper cultivation. Fertilizer compounds applied via fertigation were ammonium nitrate, calcium nitrate, monoammonium phosphate, monopotassium phosphate, potassium chloride (white), potassium sulfate, potassium nitrate and magnesium sulfate. The amounts of macronutrients applied in SC and NC treatments are given in Table 2. In fertigation management, application of the nutrient solution started at 102 DAT and lasted until 335 DAT. Nutrient quantities varied during the crop cycle, depending on the water amount applied and the nutrient concentration in the solution.

\section{Features evaluated}

Plant growth rate (PGR) was obtained by dividing plant height by number of growth days. Height was measured from the neck of the plant to the apex using a measuring tape. Readings were taken, at $35,55,85,105,120,140$, $165,180,195$, and 260 DAT, until the beginning of the third crop cycle, during flowering, fruiting and harvest (Figures 2A-D). The peppers were harvested from 185 to $350 \mathrm{DAT}$, when the fruits reached the characteristic color of the cultivar. During this period, 21 harvests were performed, which were added as one of the fruit traits. Fruit characteristics evaluated included fresh fruit mass (FFM), fruit weight harvested per plant (g per plant), number of fruits (NF), average number of fruits harvested per plant, fruit average mass (FAM), ratio of FFM to NF (g), fruit dry mass percentage (FDMP) determined in a forced ventilation oven at $60^{\circ} \mathrm{C}$ until constant mass, ratio of the 20 fruit dry mass samples to the fresh mass samples, expressed as percent, fruit dry mass (FDM), FFM product with FDMP fraction, (g per plant), productivity (PROD),

Table 2 - Quantities of macronutrients (kg ha ${ }^{-1}$ ) applied in soil cover (SC) and no soil cover (NC) treatments.

\begin{tabular}{cccccc}
\hline $\mathrm{N}$ & $\mathrm{P}_{2} \mathrm{O}_{5}$ & $\mathrm{~K}_{2} \mathrm{O}$ & $\mathrm{Ca}$ & $\mathrm{Mg}$ & $\mathrm{SO}_{4}$ \\
\hline \multicolumn{7}{c}{$\mathrm{kg} \mathrm{ha}^{-1}$} & \multicolumn{2}{c}{ Soil cover (SC) } \\
\hline 136 & 196 & 812 & 69 & 4 & 97 \\
\hline \multicolumn{7}{c}{ No soil cover (NC) } \\
185 & 279 & 1160 & 93 & 4 & 139 \\
\hline
\end{tabular}

Nitrogen (N), Diphosphorus Pentoxide $\left(\mathrm{P}_{2} \mathrm{O}_{5}\right)$, Potassium Oxide $\left(\mathrm{K}_{2} \mathrm{O}\right)$, Calcium (Ca), Magnesium (Mg), Sulphate $\left(\mathrm{SO}_{4}\right)$. 


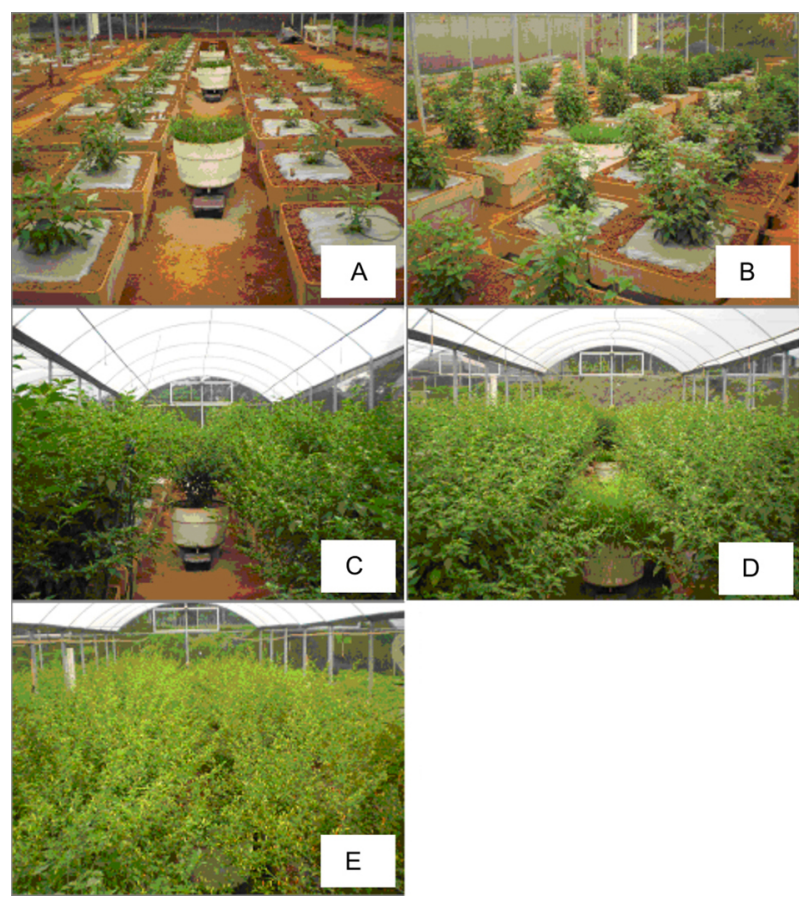

Figure 2 - Growth stages of the pepper crop. 50 days after transplantation (DAT) (A); 100 DAT (B); 150 DAT (C); 200 DAT (D), and 250 DAT (E).

FFM product (in $\mathrm{kg}$ ) with number of plants per hectare, $\left(\mathrm{kg} \mathrm{ha}^{-1}\right)$.The irrigation water use efficiency (IWUE) was determined by the ratio of crop yield to amount of water applied to treatments, according to Eq. (1).

$I W U E=\frac{P R O D}{V}$

where: IWUE is the irrigation water use efficiency $(\mathrm{kg}$ $\left.\mathrm{m}^{-3}\right), P R O D$ is the productivity $\left(\mathrm{kg} \mathrm{ha}^{-1}\right)$, and $V$ is the amount of water applied to irrigation during the crop cycle $\left(\mathrm{m}^{3} \mathrm{ha}^{-1}\right)$. The nutrient use efficiency of $\mathrm{N}, \mathrm{P}$ and $\mathrm{K}$ were determined, respectively, by Eq. (2), (3) and (4), by the ratio between PROD and amount of nutrient applied in the treatments. The value of fertilizer use efficiency (Eq. (5)) was obtained through the ratio between PROD and the sum of the nutrient quantities (NPK) applied in the treatments.

$N U E=\frac{P R O D}{N}$

where: NUE is the nitrogen use efficiency $\left(\mathrm{kg} \mathrm{kg}^{-1}\right)$, $P R O D$ is the productivity $\left(\mathrm{kg} \mathrm{ha}^{-1}\right)$, and $\mathrm{N}$ is the amount of nutrient $\mathrm{N}$ applied in the forms of $\mathrm{NO}_{3}$ and $\mathrm{NH}_{4}$ during the crop cycle $\left(\mathrm{kg} \mathrm{ha}^{-1}\right)$.

$P U E=\frac{P R O D}{P}$

where: $P U E$ is the phosphorus use efficiency $\left(\mathrm{kg} \mathrm{kg}^{-1}\right)$, $P R O D$ is the productivity $\left(\mathrm{kg} \mathrm{ha}^{-1}\right)$, and $P$ is the amount of nutrient $\mathrm{P}$ applied as $\mathrm{P}_{2} \mathrm{O}_{5}$ during the crop cycle $\left(\mathrm{kg} \mathrm{ha}^{-1}\right)$.
$K U E=\frac{P R O D}{K}$

where: KUE is the potassium use efficiency $\left(\mathrm{kg} \mathrm{kg}^{-1}\right)$, $P R O D$ is the productivity $\left(\mathrm{kg} \mathrm{ha}^{-1}\right)$, and $K$ is the amount of nutrient $\mathrm{K}$ applied as $\mathrm{K}_{2} \mathrm{O}$ during the crop cycle $\left(\mathrm{kg} \mathrm{ha}^{-1}\right)$.

$N P K U E=\frac{P R O D}{N P K}$

where: NPKUE is the NPK use efficiency $\left(\mathrm{kg} \mathrm{kg}^{-1}\right), P R O D$ is the productivity $\left(\mathrm{kg} \mathrm{ha}^{-1}\right)$, and $N P K$ is the amount of nutrient NPK applied, respectively, in the forms of $\mathrm{NO}_{3}$ and $\mathrm{NH}_{4}, \mathrm{P}_{2} \mathrm{O}_{5}$ and as $\mathrm{K}_{2} \mathrm{O}$ during the crop cycle $\left(\mathrm{kg} \mathrm{ha}^{-1}\right)^{3}$.

\section{Data analysis}

Data from each experiment (soil type) were interpreted individually in terms of the adopted experimental design. The analysis of variance, comparison of means, and regression of the traits evaluated were performed using SAS software (Statistical Analysis System Institute, 2001). For the coverage factor (qualitative variable), the Tukey test was used at $5 \%$ probability by the PROC GLM procedure. For the frequency factor (quantitative variable), the procedure PROC REG was used for the regression test, with unfolding of the degrees of freedom of the orthogonal polynomials. The regression models tested were linear, quadratic, and cubic. The model was chosen based on the biological significance, significance of the regression coefficients, $5 \%$ probability level, the $\mathrm{F}$ test, and the highest determination coefficient, $\mathrm{R}^{2}$.

\section{Results and Discussion}

\section{Vegetative responses}

The comparison of PGR mean values (Figure 3) showed that SC gave higher PGRs at 55 and 85 DAT readings in sandy loam soil and at 55, 85, 165, 195, and 260 DAT, in loamy soil, compared to NC. The SC treatment increased PGR by $21.8 \%$ and $23.8 \%$, respectively, in sandy loam soil and by $28.2 \%, 22.4 \%, 5.8 \%, 7.5 \%$, and $4.7 \%$ in loamy soil. In the same cultivation environment, Monteiro et al. (2008) observed that plastic mulching increased PGR in melon by at least $42 \%$ compared to plants grown in the soil without mulching. According to Haynes (1987), increases in plant growth from mulching could be attributed to changes in soil and air temperatures, soil water balance, and nutrient availability. In our experiments, soil temperature may have influenced up to 120 DAT, because during this period, soil shading by pepper plants was only partial. The water penetration depth and the amount of nutrients were the same during this period. From 120 to 180 DAT, the main influences were a combination of temperature, water, and nutrients, while after 180 DAT, growth effects were caused primarily by water and nutrient availability. In the sandy loam soil, differences in the amounts of water and nutrients 
between SC and NC treatments did not affect PGR during 120 DAT. In contrast, the SC treatment was superior to the NC treatment in the loamy soil after 120 DAT, despite water and nutritional restrictions. Loamy soils received more beneficial effects from plastic mulch than sandy loam soils. Ten readings were taken for PGR values in loamy soils and six were positive for SC treatment and the other four showed no difference between SC and NC. In the sandy loam soil; however, only two readings were favorable for SC and the other readings were equal. The beneficial effects of mulching on PGR could be explained by the greater flow of capillary water in the loamy soil in relation to the sandy loam, since capillarity favors greater evaporation of soil water. Monteiro et al. (2008), in a similar cultivation trial with a different crop, reported a more pronounced effect of mulching on sandy loam and attributed this result to higher saturated hydraulic conductivity of the sandy loam soil compared to the loamy soil.

Regarding the effects of fertigation frequency (Figure 3), the mean PGR values during the period from 140 to 180 DAT showed that PGR with 12 fertigation events every three days was higher than for three fertigation events in the sandy loam soil. PGR increased $9.4 \%$ on average, which corresponds to an increase of $0.57 \mathrm{~cm} \mathrm{~d}^{-1}$ or $22.9 \mathrm{~cm}$ in absolute terms. In the loamy soil, the mean PGR values in the period from 85 to 105 DAT were higher with 12 fertigation events every three days than with three fertigation events. The increase in PGR was $19.2 \%$, which corresponds to an increase of $0.45 \mathrm{~cm} \mathrm{~d}^{-1}$ or $9.0 \mathrm{~cm}$ in absolute terms. In the loamy soil,

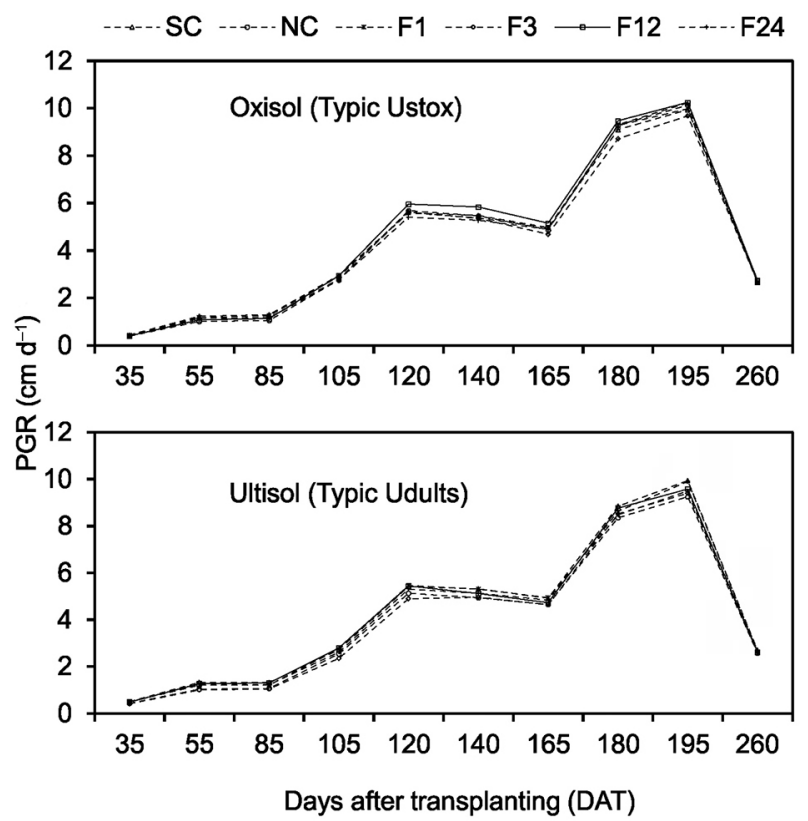

Figure 3 - Average values of daily plant growth rate (PGR) in sandy loam and loamy soils. Treatments $\mathrm{SC}=$ soil cover and $\mathrm{NC}=$ no soil cover. Irrigation frequencies: 1 (F1), 3 (F3), 12 (F12) and 24 (F24) fertigation every three days. plastic mulching with a frequency of 12 fertigation events every three days increased PGR by $17.7 \%$ compared to soil without mulching. Gadissa and Chemeda (2009) studied the effects of different drip irrigation levels and different planting methods on pepper crop yield in Ethiopia and found that a $50 \%$ reduction in irrigation decreased yield by 48.3 and $74.4 \%$ in the normal and double row planting methods, respectively, while a $25 \%$ reduction in irrigation decreased yield by 22.8 and $47.7 \%$ under the same planting methods.

\section{Productive responses}

Regarding FFM (Table 3), SC treatment resulted in lower mean values in sandy loam and loamy soils compared to $\mathrm{NC}$, with reductions of 20 and $26.1 \%$ in sandy loam and loamy soils, respectively. In the sandy loam soil, $2078 \mathrm{~g}$ of fruits per plant were harvested with mulching compared to $2598 \mathrm{~g}$ with no mulching, while in the loamy soil, the yield was 2305 and $3120 \mathrm{~g}$, respectively. Differences in the effects of fertigation frequency did not reach

Table 3 - Average values of fresh fruit mass (FFM), number of fruits (NF), fruit average mass (FAM), fruit dry mass percentage (FDMP), and fruit dry mass (FDM) in pepper crops due to different soil covers and different irrigation frequencies in Oxisol (Typic Ustox) and Ultisol (Typic Udults).

\begin{tabular}{|c|c|c|c|c|c|}
\hline Treatments & FFM & NF & FAM & FDMP & FDM \\
\hline & g per plant & fruit per plant & g per fruit & $\%$ & g per plant \\
\hline \multicolumn{6}{|c|}{ Oxisol (Typic Ustox) } \\
\hline \multicolumn{6}{|l|}{ Cover } \\
\hline SC & $2078.40 \mathrm{~b}$ & $3884 \mathrm{~b}$ & $0.51 b$ & 28.31 a & $577.01 b$ \\
\hline NC & $2598.10 \mathrm{a}$ & 4314 a & $0.58 \mathrm{a}$ & $27.11 b$ & $693.36 \mathrm{a}$ \\
\hline DMS & 227.53 & 384 & 0.03 & 0.60 & 61.09 \\
\hline \multicolumn{6}{|l|}{ Frequencies $^{1}$} \\
\hline 1 & 2303.30 & 4028 & 0.55 & 27.88 & 631.29 \\
\hline 3 & 2283.50 & 3913 & 0.55 & 27.34 & 614.62 \\
\hline 12 & 2443.80 & 4280 & 0.54 & 27.54 & 655.99 \\
\hline 24 & 2322.30 & 4175 & 0.54 & 28.09 & 638.84 \\
\hline DMS & 431.29 & 727 & 0.05 & 1.14 & 115.79 \\
\hline \multicolumn{6}{|c|}{ Ultisol (Typic Udults) } \\
\hline \multicolumn{6}{|l|}{ Cover } \\
\hline SC & $2304.70 \mathrm{~b}$ & $4184 \mathrm{~b}$ & $0.52 b$ & 28.04 & $637.03 b$ \\
\hline NC & $3119.90 \mathrm{a}$ & $5123 a$ & $0.58 \mathrm{a}$ & 27.55 & 846.99 a \\
\hline DMS & 298.14 & 460 & 0.03 & 0.60 & 75.75 \\
\hline \multicolumn{6}{|l|}{ Frequencies $^{1}$} \\
\hline 1 & 2794.80 & 4905 & 0.54 & 28.44 & 789.04 \\
\hline 3 & 2625.80 & 4527 & 0.56 & 27.66 & 718.58 \\
\hline 12 & 2883.90 & 4849 & 0.55 & 27.46 & 767.27 \\
\hline 24 & 2544.70 & 4332 & 0.56 & 27.64 & 693.16 \\
\hline DMS & 565.12 & 872 & 0.06 & 1.15 & 143.59 \\
\hline
\end{tabular}

*Values between lines followed by letters differ statistically by Tukey test at $5 \%$ probability level; ${ }^{1}$ Frequency: $1,3,12$ and 24 fertigation every three days; DMS = Minimum significant difference; treatments SC = soil cover and NC = no soil cover. 
significance for FFM in the sandy loam and loamy soils (Table 3). The mean FFM value for the highest frequency was 2338 and 2712 g per plant for the sandy loam and loam soil, respectively. The greatest variation in high and low FFM values was 160 g per plant (7\%) between 12 and 3 fertigation events every three days in the sandy loam soil and 339 g per plant (13\%) between 12 and 24 fertigation events in the loamy soil.

For NF (Table 3), the mean values indicated that $\mathrm{SC}$ treatment resulted in lower NF per plant in the sandy loam and loamy soils compared to $\mathrm{NC}$, with reductions of 10.0 and $18.1 \%$, respectively. In the sandy loam, approximately 3884 fruits per plant were harvested after SC treatment compared to 4314 fruits with NC. In the loamy soil, the NF was 4184 fruits per plant with mulching and 5123 without mulching. Paula et al. (2011) found that the highest NF among the treatments tested for different $\mathrm{CO}_{2}$ doses by drip irrigation was 695 fruits per plant. Azevedo et al. (2005), working with the same pepper in the field in a semi-arid climate region and testing different irrigation depths, observed that the highest absolute value was 1691 fruits per plant. Under similar conditions in the same location, Chaves et al. (2006) tested different $\mathrm{N}$ doses in pepper cultivation and obtained a maximum value of 1452 fruits per plant. Similar to FFM, differences in NF attributable to fertigation frequencies did not reach significance in the sandy loam and loamy soils (Table 3). The mean NF value for the frequencies on the respective soils was 4099 and 4653 fruits per plant. The largest variation in high and low NF values was between 12 and 3 fertigation events every three days in the sandy loam soil at 367 fruits $(9 \%)$ and 573 fruits $(12 \%)$, between the frequencies of 1 and 24 fertigation events in the loamy soil. As for mulching (Table 3), despite the similarity in its effects on FFM and NF in sandy loam and loamy soils, the differences between the means of NF were relatively small in the sandy loam soil and larger in the loamy soil. This indicates that differences in FFM were due to variations in FAM in the sandy loam soil and NF in the loamy soil. FAM is a very important yield component, especially when considering the costs of harvesting and marketing the fruit. Similar to the results that Paula et al. (2011) and Chaves et al. (2006) had for FFM and NF, the FFM magnitude per plant depends exclusively on the NF per plant. The mean values of FAM (Table 3) with SC treatment were $12.7 \%$ lower for plants in sandy loam soils and $9.8 \%$ lower in loamy soils than with NC treatment. In the sandy loam soil, FAM was approximately $0.51 \mathrm{~g}$ per fruit with SC treatment and $0.58 \mathrm{~g}$ with $\mathrm{NC}$, while in the loamy soil, FAM was 0.52 and $0.58 \mathrm{~g}$ per fruit with the respective treatments. Azevedo et al. (2005), Chaves et al. (2006), and Paula et al. (2011) found FAM values of 0.91, 0.83 , and $0.77 \mathrm{~g}$ per fruit, respectively.

Following the trend of the FFM and NF results, the effect of fertigation frequencies on FAM was not significant in the sandy loam and loamy soils (Table 3). The mean FAM value for the frequencies was 0.54 and $0.55 \mathrm{~g}$ per fruit for the respective soils. The largest differences between higher and lower FAM values were $0.019 \mathrm{~g}(4 \%)$ between the 3 and 24 fertigation events every three days in the sandy loam soil and $0.017 \mathrm{~g}(3 \%)$ between 3 and 1 fertigation events in the loamy soil.

Considering the soil mulching factor in isolation, we found that the percent difference in FAM was proportionally larger in the sandy loam soil and smaller in the loamy soil compared to the differences in NF (Table 3). This reinforces the aforementioned result that FFM is the most important FAM characteristic in sandy loam soils and NF in loamy soils. When NF is smaller, the plant can provide greater amounts of water and nutrients to each fruit, favoring larger FAMs and, consequently, larger FFMs per plant. Azevedo et al. (2005) also observed that pepper production and FAM tended to increase at increasing irrigation depth, while NF per plant did not change with irrigation depth. However, there is a limit between NF and FAM, which defines the characteristic that results in the largest FFM per plant and this limit depends on the soil type. In financial terms, the cost of harvesting peppers is relatively lower in the sandy loam soil than in the loamy soil, due to the greater FFM per plant.

For FDMP per plant (Table 3), the mean values indicated that SC treatment resulted in $4.4 \%$ higher FDMP for plants in the sandy loam soil compared to the NC treatment. However, in the loamy soil, the mean FDMP values were approximately equal between the SC and NC treatments. In the sandy loam soil, FDMP was approximately $28.3 \%$ in the SC treatment and $27.1 \%$ in the NC, while in the loamy soil, FDMP was 28.0 and 27.6 $\%$ in the respective treatments. Paula et al. (2011) found that the highest FDMP was approximately $22.7 \%$. The values did not show significant differences for FDMP and fertigation frequency in sandy loam and loamy soils (Table 3). The mean FDMP value for the tested frequencies was 27.7 and $27.8 \%$ for the respective soils. The greatest variation between higher and lower FDMP values was $0.8 \%$, between 24 and 3 fertigation events every three days in the sandy loam soil and $1.0 \%$, between 1 and 12 fertigation events in the loamy soil. The mean FDM values (Table 3) showed that the effect of SC was lower in sandy loam and loamy soils compared to the NC. The FDM value was $16.8 \%$ lower with the SC treatment in the sandy loam and $24.8 \%$ lower in loamy soils than with the NC treatment. In the sandy loam soil, FDM was approximately $577 \mathrm{~g}$ per plant in the SC treatment and 693 g per plant in NC, while in the loamy soil, FDM was 637 and $847 \mathrm{~g}$ per plant with the respective treatments.

Over time, fertigation frequencies did not reach the minimum significant difference in FDM in the sandy loam and loamy soils (Table 3). The mean FDM value at different frequencies was $635 \mathrm{~g}$ per plant for the sandy loam and 742 for the loamy soil. The highest variation ranges were $41 \mathrm{~g}$ per plant $(7 \%)$, between the frequencies of 12 and 3 fertigation events every three days in the sandy loam soil, respectively, for higher and lower FDM values and 96 g per plant (14 \%) between the frequencies of 1 and 24 fertigation events in the loamy soil. 
In terms of soil covering, a joint evaluation of the characteristics FFM, FDMP, and FDM revealed that the differences between the percentage values of FDM were relatively smaller in the sandy loam soil and larger in the loamy soil than those found for FFM (Table 3). This indicates that FDM was the most important relative characteristic of FDMP in the sandy loam soil, while in the loamy soil, FDMP did not influence FDM. However, differences between the absolute FDM values prevail over the relative ones, and therefore the FFM is considered the most important in terms of yield.

The characteristics, $\mathrm{PROD}_{1}$ and $\mathrm{PROD}_{2}$ (Figure 4), in the sandy loam soil with SC showed losses of 1890 and $5198 \mathrm{~kg} \mathrm{ha}^{-1}$, respectively, compared to NC. In the loamy soil, losses with SC treatment compared to NC treatment were 2965 and $8153 \mathrm{~kg} \mathrm{ha}^{-1}$, respectively. The average values of $\mathrm{PROD}_{1}$ and $\mathrm{PROD}_{2}$ in the sandy loam soil were 8503 and $23,382 \mathrm{~kg} \mathrm{ha}^{-1}$, respectively, and in the loamy soil 9863 and 27,193 $\mathrm{kg} \mathrm{ha}^{-1}$. In general, the lower values of characteristics FFM, NF, FAM, FDM, PROD and $\mathrm{PROD}_{2}$ of plants grown in soil covered with plastic are probably due to the approximately $30 \%$ deficit in the irrigation depth and, consequently, in the amount of fertilizer applied from 122 to 350 DAT of pepper (flowering, fruiting, and harvesting period).

Azevedo et al. (2005) and Chaves et al. (2006) found that the highest yield values were18,871 and 16,473 kg

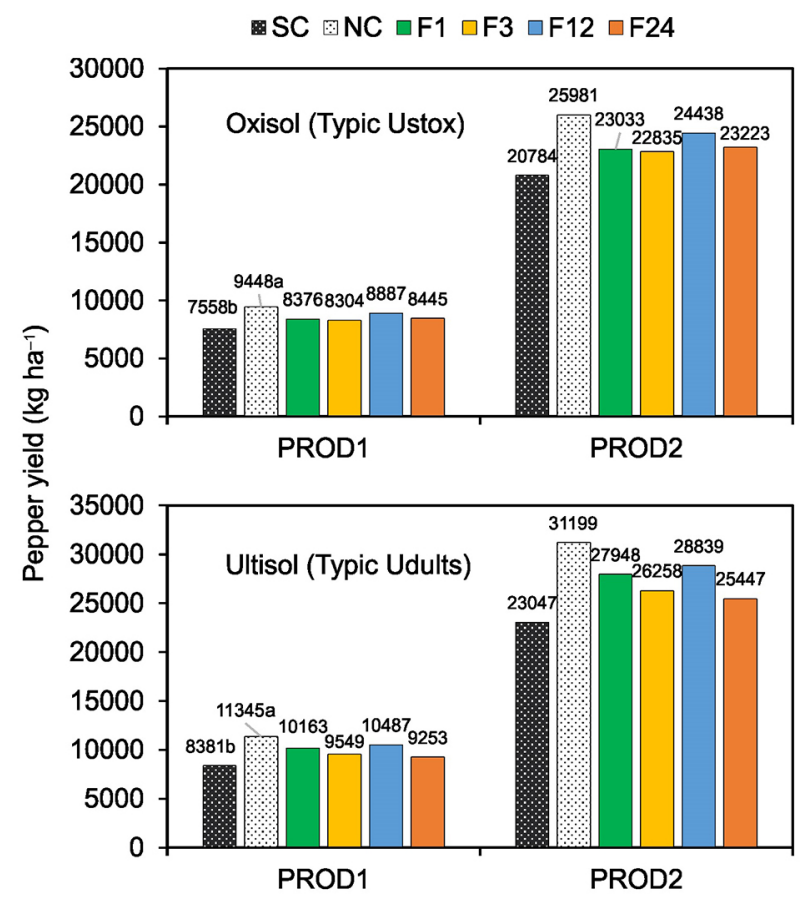

Figure 4 - Pepper yield $\left(\mathrm{kg} \mathrm{ha}^{-1}\right)$ for the populations of 3636 (PROD1) and 10000 plants ha ${ }^{-1}$ (PROD2) due to different soil covers and irrigation frequencies in Oxisol (Typic Ustox) and Ultisol (Typic Udults). Treatments SC - soil cover and NC - no soil cover. Irrigation frequencies: 1 (F1), 3 (F3), 12 (F12), and 24 (F24) fertigation every three days. $\mathrm{ha}^{-1}$, respectively, for a population of 13,889 plants ha-1. Morales-Garcia et al. (2011) studied the effect of saline drip irrigation on different growth stages of two pepper cultivars (Red Knight and Early Sunsation) planted with and without black soil cover and found that the total yield of marketable ripe fruits was higher with soil covering in all periods under saline irrigation, showing the potential benefits of mulching for pepper cultivation. Liang et al. (2011) evaluated the response of Malagueta peppers (Capsicum annuum L.) to soil cover practices in greenhouse experiments in China and concluded that crop yield was higher under all soil cover conditions. Compared to treatment without mulching, yield was increased by 82.3 $\%, 65.0 \%$, and $111.5 \%$ in $2008 ; 38.1 \%, 17.4 \%$, and $46.5 \%$ in 2009 ; and $14.3 \%, 6.5 \%$, and $19.6 \%$ in 2010 , with the use of wheat straw mulch, plastic covering, and plastic and wheat straw, respectively.

The mean values for $\mathrm{PROD}_{1}$ and $\mathrm{PROD} 2{ }_{1}$ in the average of the irrigation frequency treatments were 8503 and $23,382 \mathrm{~kg} \mathrm{ha}^{-1}$, respectively, in the sandy loam soil, and 9863 and $27,193 \mathrm{~kg} \mathrm{ha}^{-1}$ in the loamy soil. The greatest variation between high and low mean values of PROD $_{1}$ and $\mathrm{PROD}_{2}$ occurred with 12 and 3 fertigation events, respectively, every three days in the sandy loam soil, and between 12 and 24 fertigation events in the loamy soil. The variations in $\mathrm{PROD}_{1}$ and $\mathrm{PROD}_{2}$ were 583 and 1603 $\mathrm{kg} \mathrm{ha}^{-1}$ in the sandy loam soil, respectively, and 1233 and $3392 \mathrm{~kg} \mathrm{ha}^{-1}$, in the loamy soil.

\section{Water and nutrient use efficiency}

The mean values for WUE (Table 4) were $15.3 \%$ higher with SC in the sandy loam soil compared to NC. However, in the loamy soil, the mean WUE values were about the same between the SC and NC treatments. In the sandy loam, WUE was $2.18 \mathrm{~kg} \mathrm{~m}^{-3}$ with the SC treatment and $1.89 \mathrm{~kg} \mathrm{~m}^{-3}$ with $\mathrm{NC}$, while in the loamy soil, WUE was 2.41 and $2.71 \mathrm{~kg} \mathrm{~m}^{-3}$, with the respective treatments. Azevedo et al. (2005), working with the same pepper in a field in a semi-arid climate region and testing the effects of different irrigation depths, observed that the highest absolute WUE value was $1.85 \mathrm{~kg} \mathrm{~m}^{-3}$ and the mean value between treatments was $1.74 \mathrm{~kg} \mathrm{~m}^{-3}$. Monteiro et al. (2014) investigated the effects of water and nutrient use on yield of melons fertigated by underground drip in different soil types and found an increase in WUE and NPKUE due to the use of mulching in the sandy loam soil. The effect of fertigation frequency on WUE (Table 4) did not reach significance for differences between sandy loam and loamy soils. The mean WUE values were 2.04 and $2.36 \mathrm{~kg} \mathrm{~m}^{-3}$ for the respective soils. The greatest variation between the highest and lowest WUE values for the frequencies of 12 and 3 fertigation events every three days was $0.21 \mathrm{~kg} \mathrm{~m}^{-3}(11 \%)$ in the sandy loam soil and $0.27 \mathrm{~kg} \mathrm{~m}^{-3}(12 \%)$ between the frequencies of 12 and 24 fertigation events in the loamy soil.

The results corroborate the increase in WUE by the pepper crop by saving approximately $30 \%$ in the 
Table 4 - Average values of nitrogen use efficiency (NUE), phosphorus use efficiency (PUE), potassium use efficiency (KUE), NPK use efficiency (NPKUE) and water use efficiency (WUE) in pepper crops in sandy loam and loamy soils.

\begin{tabular}{|c|c|c|c|c|c|}
\hline Treatments & NUE & PUE & KUE & NPKUE & WUE \\
\hline & \multicolumn{4}{|c|}{$\mathrm{kg} \mathrm{kg}^{-1}$} & $\mathrm{~kg} \mathrm{~m}^{-3}$ \\
\hline \multicolumn{6}{|c|}{ Oxisol (Typic Ustox) } \\
\hline \multicolumn{6}{|l|}{ Cover } \\
\hline SC & 48.70 & 18.54 & $8.53 a^{*}$ & 5.18 & $2.18 a^{*}$ \\
\hline NC & 44.47 & 18.15 & $7.45 \mathrm{~b}$ & 4.75 & $1.89 \mathrm{~b}$ \\
\hline DMS & 4.81 & 1.83 & 0.84 & 0.51 & 0.21 \\
\hline \multicolumn{6}{|c|}{ Frequencies $^{1}$} \\
\hline 1 & 45.13 & 17.86 & 7.73 & 4.81 & 1.99 \\
\hline 3 & 44.55 & 17.63 & 7.61 & 4.74 & 1.93 \\
\hline 12 & 48.74 & 19.33 & 8.43 & 5.23 & 2.14 \\
\hline 24 & 47.91 & 18.55 & 8.20 & 5.07 & 2.09 \\
\hline DMS & 9.12 & 3.47 & 1.60 & 0.98 & 0.40 \\
\hline \multicolumn{6}{|c|}{ Ultisol (Typic Udults) } \\
\hline \multicolumn{6}{|l|}{ Cover } \\
\hline SC & 54.03 & $20.07 b$ & 9.65 & 5.82 & 2.41 \\
\hline NC & 54.75 & $22.59 \mathrm{a}$ & 9.32 & 5.89 & 2.31 \\
\hline DMS & 5.41 & 2.19 & 0.92 & 0.58 & 0.23 \\
\hline \multicolumn{6}{|l|}{ Frequencies $^{1}$} \\
\hline 1 & 56.33 & 22.10 & 9.84 & 6.07 & 2.45 \\
\hline 3 & 52.21 & 20.53 & 9.12 & 5.62 & 2.27 \\
\hline 12 & 57.82 & 22.66 & 10.05 & 6.21 & 2.50 \\
\hline 24 & 51.21 & 20.05 & 8.94 & 5.51 & 2.23 \\
\hline DMS & 10.25 & 4.15 & 1.76 & 1.10 & 0.44 \\
\hline
\end{tabular}

irrigation depth applied to the plastic mulching and, consequently, electricity consumption. The marked difference in the sandy loam soil and the equality in the loamy soil as determined by SC suggested that mulching was beneficial for pepper cultivation under greenhouse conditions, similar to those of the experimental area. Monteiro et al. (2013) studied water consumption of melons in a greenhouse with two soil classes, sandy loam and loamy, and found that mulching saved $27 \mathrm{~mm}$ of water during the 84-day cycle by reducing evaporation. In terms of volume, this value shows that each plant received $175.2 \mathrm{~L}$ of water during the 84 days of cultivation, on average, while in the mulching treatments, the water requirement was $160.2 \mathrm{~L}$ of water per plant. For NUE, PUE, KUE, and NPKUE (Table 4), the mean values indicated that $\mathrm{SC}$ resulted in higher KUE and equal NUE, PUE, and NPKUE in the sandy loam soil compared to NC. In the loamy soil, SC caused lower PUE than NC, but the values of NUE, KUE and NPKUE were rather equal. Plastic mulching provided an increase of $14.5 \%$ in KUE and a decrease of 11.2 $\%$ in PUE.

Following the same trend for WUE, differences in values at different fertigation frequencies were not significant in the sandy loam and loamy soils (Table 4). The mean frequency values were $46.58 \mathrm{~kg} \mathrm{~kg}^{-1}$ for $\mathrm{N}, 18.34 \mathrm{~kg} \mathrm{~kg}^{-1}$ for $\mathrm{P}, 7.99 \mathrm{~kg} \mathrm{~kg}^{-1}$ for $\mathrm{K}$, and $4.96 \mathrm{~kg}$ $\mathrm{kg}^{-1}$ of NPK, respectively, for NUE, PUE, KUE, and NPKUE in the sandy loam soil, and $54.39 \mathrm{~kg} \mathrm{~kg}^{-1} \mathrm{~N}$, $21.34 \mathrm{~kg} \mathrm{~kg}^{-1} \mathrm{P}, 9.49 \mathrm{~kg} \mathrm{~kg}^{-1} \mathrm{~K}$, and $5.85 \mathrm{~kg} \mathrm{~kg}^{-1} \mathrm{NPK}$ in the loamy soil. In the sandy loam, the greatest variations between the high and low values of NUE, PUE, KUE, and NPKUE were $4.19 \mathrm{~kg} \mathrm{~kg}^{-1}$ of $\mathrm{N}(9 \%)$, $1.70 \mathrm{~kg} \mathrm{~kg}^{-1}$ of $\mathrm{P}(10 \%), 0.82 \mathrm{~kg} \mathrm{~kg}^{-1}$ of $\mathrm{K}(11 \%)$, and $0.49 \mathrm{~kg} \mathrm{~kg}^{-1}$ NPK (10\%), respectively, between the frequencies of 12 and 3 fertigation events every three days. For the loamy soil, the highest ranges were 6.61 $\mathrm{kg} \mathrm{kg}^{-1}$ of $\mathrm{N}(11 \%), 2.61 \mathrm{~kg} \mathrm{~kg}^{-1}$ of $\mathrm{P}(10 \%), 1.11 \mathrm{~kg}$ $\mathrm{kg}^{-1}$ of $\mathrm{K}(10 \%)$, and $0.70 \mathrm{~kg} \mathrm{~kg}^{-1} \mathrm{NPK}(10 \%)$, between the frequencies of 12 and 24 fertigation events.

The results of nutrient yield increase efficiency of nutrient utilization by the pepper crop, according to the savings of approximately $30 \%$ in nutrients applied via irrigation water due to the use of plastic soil cover. In general, plastic mulching shows more benefits than non-plastic mulching, indicating that mulching is recommended for greenhouse cultivation under edaphoclimatic conditions similar to those in the experimental site.

\section{Conclusions}

Water and nutrient use efficiency did not differ statistically with and without mulching. However, the savings of approximately $30 \%$ on water and nutrients with plastic soil cover use supports the recommendation for mulching in pepper crops under conditions of water source limitation. The use of plastic film as soil cover decreased FFM, NF, FAM, and FDM in sandy loam and loamy soils, but PUE only in loamy soil. Mulching had no effect on FDMP, WUE, NUE, KUE, and NPKUE in loamy soils or on NUE, PUE, and NPKUE in sandy loam soils. However, mulching increased FDMP, WUE, and KUE in the sandy loam soil. The optimal frequency of irrigation and fertigation indicated for pepper crops under operational conditions of the experimental site is once every three days.

\section{Acknowledgments}

This study was financed in part by the Coordination for the Improvement of Higher Level Personnel - Brazil (CAPES) - Finance Code 001.

\section{Authors' Contributions}

Conceptualization: Chaves, S.W.P.; Coelho, R.D. Data acquisition: Chaves, S.W.P.; Coelho, R.D.; Tapparo, S.A. Data analysis: Chaves, S.W.P.; Coelho, R.D.; Costa, J.O.; Tapparo, S.A. Design of methodology: Chaves, S.W.P.; Coelho, R.D.; Tapparo, S.A. Writing and editing: Chaves, S.W.P.; Coelho, R.D.; Costa, J.O.; Tapparo, S.A. 


\section{References}

Allen, R.G.; Wright, J.L.; Pruitt, W.O.; Pereira, L.S.; Jensen, M.E. 2007. Water requirements. p. 208-288. In: Hoffman, G.J.; Evans, R.G.; Jensen, M.E.; Martin, D.L.; Elliott, R.L. Design and operation of farm irrigation systems. ASABE, St. Joseph, MI, USA.

Alenazi, M.; Abdel-Razzak, H.; Ibrahim, A.; Wahb-Allah, M.; Alsadon, A. 2015. Response of muskmelon cultivars to plastic mulch and irrigation regimes under greenhouse conditions. Journal of Animal and Plant Sciences 25: 1398-1410.

Alvares, C.A.; Stape, J.L.; Sentelhas, P.C.; Gonçalves, J.L.M.; Sparovek, G. 2013. Köppen's climate classification map for Brazil. Meteorologische Zeitschrift 22: 711-728.

Amayreh, J.; Al-Abed, N. 2005. Developing crop coefficients for field-grown tomato (Lycopersicon esculentum Mill.) under drip irrigation with black plastic mulch. Agricultural Water Management 73: 247-254.

Azevedo, B.M.; Chaves, S.W.P.; Medeiros, J.F.; Aquino, B.F.; Bezerra, F.M.L.; Viana, T.V.A. 2005. Hot pepper yield as affected by irrigation water depths. Revista Ciência Agronômica 36: 268-273 (in Portuguese, with abstract in English).

Chaves, S.W.P.; Azevedo, B.M.; Aquino, B.F.; Viana, T.A.; Morais, N.B. 2006. Hot pepper yield in function of different levels of nitrogen. Revista Ciência Agronômica 37: 19-24 (in Portuguese, with abstract in English).

Ćosić, M.; Stričević, R.; Djurović, N.; Moravčević, D.; Pavlović, M.; Todorović, M. 2017. Predicting biomass and yield of sweet pepper grown with and without plastic film mulching under different water supply and weather conditions. Agricultural Water Management 188: 91-100.

Costa, J.O.; Coelho, R.D.; Barros, T.H.S.; Fraga Junior, E.F.; Fernandes, A.L.T. 2020. Canopy thermal response to water deficit of coffee plants under drip irrigation. Irrigation and Drainage 69: 472-482.

Ding, D.; Feng, H.; Zhao, Y.; Hill, R.L.; Yan, H.; Chen, H.; Dong, Q. 2019. Effects of continuous plastic mulching on crop growth in a winter wheat-summer maize rotation system on the Loess Plateau of China. Agricultural and Forest Meteorology 271: 385397.

Gadissa, T.; Chemeda, D. 2009. Effects of drip irrigation levels and planting methods on yield and yield components of green pepper (Capsicum annuum, L.) in Bako, Ethiopia. Agricultural Water Management 96: 1673-1678.

Gerçek, S.; Demirkaya, M. 2021. Impact of colored water pillows on yield and water productivity of pepper under greenhouse conditions. Agricultural Water Management 250: 106835.

Haynes, R.J. 1987. The use of polyethylene mulches to change soil microclimate as revealed by enzyme activity and biomass nitrogen, sulphur and phosphorus. Biology and Fertility of Soils 3: 235-240.

Kabir, M.Y.; Nambeesan, S.U.; Bautista, J.; Díaz-Pérez, J.C. 2021. Effect of irrigation level on plant growth, physiology and fruit yield and quality in bell pepper (Capsicum annuum L.). Scientia Horticulturae 281: 109902.

Liang, Y.L.; Wu, X.; Zhu, J.J.; Zhou, M.J.; Peng, Q. 2011. Response of hot pepper (Capsicum annuum L.) to mulching practices under planted greenhouse condition. Agricultural Water Management 99: $111-120$
Liao, Y.; Cao, H.X.; Xue, W.K.; Liu, X. 2021. Effects of the combination of mulching and deficit irrigation on the soil water and heat, growth and productivity of apples. Agricultural Water Management 243: 106482.

Monteiro, R.O.C.; Coelho, R.D.; Melo, P.C.; Ferraz, P.; Chaves, S.W.; Shirahige, F.H.; Piedade, S.M.D.S. 2008. Net melon performance as affected by the drip irrigation depth and mulching. Horticultura Brasileira 26: 447-451.

Monteiro, R.O.C.; Coelho, R.D.; Monteiro, P.F.C. 2014. Water and nutrient productivity in melon crop by fertigation under subsurface drip irrigation and mulching in contrasting soils. Ciência rural 44: 25-30.

Monteiro, R.O.C.; Coelho, R.D.; Monteiro, P.F.C.; Whopmans, J.; Lennartz, B. 2013. Water consumption and soil moisture distribution in melon crop with mulching and in a protected environment. Revista Brasileira de Fruticultura 35: 555-564.

Morales-Garcia, D.; Stewart, K.A.; Seguin, P.; Madramootoo, C. 2011. Supplemental saline drip irrigation applied at different growth stages of two bell pepper cultivars grown with or without mulch in non-saline soil. Agricultural Water Management 98: 893-898.

Paula, F.L.M.; Frizzone, J.A.; Paula, A.L.; Dias, C.T.S.; Soares, T.M. 2011. Tabasco pepper production with $\mathrm{CO}_{2}$ application using drip irrigation. Acta Scientiarum. Agronomy 33: 133-138 (in Portuguese, with abstract in English).

Tapparo, S.A.; Coelho, R.D.; Costa, J.O.; Chaves, S.W.P. 2019. Growth and establishment of irrigated lawns under fixed management conditions. Scientia Horticulturae 256: 108580.

Vázquez, N.; Pardo, A.; Suso, M.L.; Quemada, M. 2006. Drainage and nitrate leaching under processing tomato growth with drip irrigation and plastic mulching. Agriculture, Ecosystems \& Environment 112: 313-323.

Wang, J.; Du, G.; Tian, J.; Jiang, C.; Zhang, Y.; Zhang, W. 2021a. Mulched drip irrigation increases cotton yield and water use efficiency via improving fine root plasticity. Agricultural Water Management 255: 106992.

Wang, Z.; Li, M.; Flury, M.; Schaeffer, S.M.; Chang, Y.; Tao, Z.; Wang, J. 2021b. Agronomic performance of polyethylene and biodegradable plastic film mulches in a maize cropping system in a humid continental climate. Science of The Total Environment 786: 147460.

Zhang, H.; Miles, C.; Gerdeman, B.; LaHue, D.G.; DeVetter, L. 2021. Plastic mulch use in perennial fruit cropping systems: a review. Scientia Horticulturae 281: 109975.

Zhang, X.; Yang, L.; Xue, X.; Kamran, M.; Ahmad, I.; Dong, Z.; Han, Q. 2019. Plastic film mulching stimulates soil wet-dry alternation and stomatal behavior to improve maize yield and resource use efficiency in a semi-arid region. Field Crops Research 233: 101-113.

Zhou, L.; Feng, H.; Zhao, W. 2021. Plastic film mulching affects the critical nitrogen dilution curve of drip-irrigated maize. Field Crops Research 263: 108055.

Zong, R.; Wang, Z.; Zhang, J.; Li, W. 2021. The response of photosynthetic capacity and yield of cotton to various mulching practices under drip irrigation in northwest China. Agricultural Water Management 249: 106814. 